\title{
Role of biomarkers in understanding and treating children with asthma: towards personalized care
}

This article was published in the following Dove Press journal:

Pharmacogenomics and Personalized Medicine

20 August 2013

Number of times this article has been viewed

\author{
Jason E Lang' \\ Kathryn V Blake ${ }^{2}$ \\ 'Division of Pulmonary and Sleep \\ Medicine, Nemours Children's \\ Hospital, Orlando, FL, USA; \\ ${ }^{2}$ Center for Pharmacogenomics and \\ Translational Research, Nemours \\ Children's Clinic, Jacksonville, FL, USA
}

Both authors contributed equally to this work
Correspondence: Jason E Lang

Division of Pulmonary and Sleep

Medicine, Center for Pharmacogenomics

and Translational Research

Nemours Children's Hospital,

I 3535 Nemours Parkway, Orlando,

FL 32827, USA

$\mathrm{Tel}+\mid 4075673868$

Fax +| 407650764 |

Email jason.lang@nemours.org

\begin{abstract}
Asthma is one of the most common chronic diseases affecting children. Despite publicized expert panels on asthma management and the availability of high-potency inhaled corticosteroids, asthma continues to pose an enormous burden on quality of life for children. Research into the genetic and molecular origins of asthma are starting to show how distinct disease entities exist within the syndrome of "asthma". Biomarkers can be used to diagnose underlying molecular mechanisms that can predict the natural course of disease or likely response to drug treatment. The progress of personalized medicine in the care of children with asthma is still in its infancy. We are not yet able to apply stratified asthma treatments based on molecular phenotypes, although that time may be fast approaching. This review discusses some of the recent advances in asthma genetics and the use of current biomarkers that can help guide improved treatment. For example, the fraction of expired nitric oxide and serum Immunoglobulin $\mathrm{E}$ ( $\mathrm{IgE}$ ) (including allergen-specific $\operatorname{IgE}$ ), when evaluated in the context of recurrent asthma symptoms, are general predictors of allergic airway inflammation. Biomarker assays for secondhand tobacco smoke exposure and cysteinyl leukotrienes are both promising areas of study that can help personalize management, not just for pharmacologic management, but also education and prevention efforts.
\end{abstract}

Keywords: asthma, biomarkers, children, management

\section{Introduction}

Asthma is one of the most common chronic diseases affecting children. The number of people worldwide affected by asthma may be as high as 300 million. ${ }^{1}$ Asthma continues to pose an enormous burden on quality of life and health care costs. Despite widely publicized expert panels on asthma management and the availability of high-potency inhaled corticosteroids, asthma continues to be a leading cause of hospitalization, emergency department visits, and missed school in children. ${ }^{2}$ In 2009 , one in five of the estimated eight million children in the United States with asthma went to the emergency department for asthma. Asthma has a strong familial aggregation and can present as one of several distinct phenotypes (Table 1). Despite the high degree of heritability, external factors such as air pollution, immune sensitization, secondhand smoke, nutrition, and obesity can affect both disease risk and control of symptoms.

Asthma continues to be a disease that is diagnosed clinically, using history-taking (recurrent wheeze, cough, and dyspnea triggered by viral infections, allergen, exercise or pollutants, and response to glucocorticoids and bronchodilators), physical examination, and pulmonary function testing (reversible airflow obstruction). However, it is becoming clearer that within a population of patients diagnosed with asthma, there 
Table I Common phenotypes of childhood asthma

\begin{tabular}{|c|c|c|c|c|c|}
\hline Phenotype & Onset & Natural history & Triggers & Biomarker characteristics & Treatment \\
\hline Atopic & Infancy & chronic & Virus, allergen & Elevated IgE, FENO & Chronic: ICS \\
\hline $\begin{array}{l}\text { Virus-induced } \\
\text { wheezing }\end{array}$ & Infancy & $\begin{array}{l}\text { Resolves by } \\
\text { school age }\end{array}$ & Virus & Normal lgE, FENO & $\begin{array}{l}\text { Supportive care, } \\
\text { bronchodilators }\end{array}$ \\
\hline $\begin{array}{l}\text { Exercise- } \\
\text { induced }\end{array}$ & $\begin{array}{l}\text { School age - } \\
\text { adolescence }\end{array}$ & chronic & Exercise & $\begin{array}{l}\text { IgE, eosinophils, }{ }^{\prime 10} \\
\text { cysLTs'"1 may be elevated; } \\
\text { FENO typically normal' }\end{array}$ & $\begin{array}{l}\text { Acute: Pretreat with } \\
\text { bronchodilator, } \\
\text { Chronic: montelukast, } \\
\text { cardiopulmonary conditioning }\end{array}$ \\
\hline $\begin{array}{l}\text { Obesity- } \\
\text { related }\end{array}$ & $\begin{array}{l}\text { All ages, but more } \\
\text { common in } \\
\text { adolescence }\end{array}$ & $\begin{array}{l}\text { May resolve } \\
\text { with weight loss }\end{array}$ & Non-specific & $\begin{array}{l}\text { Typically normal lgE, } \\
\text { normal FENO }\end{array}$ & $\begin{array}{l}\text { Weight loss; ICS may be } \\
\text { less effective among obese; } \\
\text { consider LTM }\end{array}$ \\
\hline
\end{tabular}

Abbreviations: IgE, Immunoglobulin E; FENO, fractional exhaled nitric oxide; ICS, inhaled corticosteroid; cysLT, cysteinyl leukotrienes (LTC4, LTD4, and LTE4); LTM, leukotriene modifier.

exists significant heterogeneity regarding the underlying airway inflammation, hyperresponsiveness, symptom triggers, and response to anti-inflammatory medications. Most experts agree that asthma is likely to be a syndrome consisting of multiple overlapping disease entities. Unfortunately, we have not yet been successful in translating this increasing understanding of asthma into improved asthma control and reduced morbidity for children. Better methods to assess inflammatory patterns, phenotype characteristics, and likely drug response characteristics are needed to improve outcomes. This review discusses the most recent data regarding the genetics of asthma and practical biomarkers in children, and gives recommendations regarding the best studied and most feasible biomarkers for improving clinical care.

\section{Genetic markers of asthma}

Genetic biomarkers are slowly increasing our understanding of how asthma develops, and what genomic loci (along with environmental triggers) are most critical. Early studies searching for asthma susceptibility genes used familybased positional cloning techniques. The first genome-wide screen for asthma is now almost two decades old. ${ }^{3}$ Since then genome-wide linkage analyses, and both candidate gene and genome-wide association studies have offered many potential loci that are important in the development of asthma. These studies have directed our attention to the important role of T helper 2 differentiation and action, airway epithelial function, and the innate immune system. Genetic studies have shown us that even the most highly replicated risk genes appear to have only a modest impact on asthma risk. Rather, individual genes likely interact with each other (called epistasis) and the environment to promote asthma. Based on the latest analysis of the literature and considering that physician-diagnosed asthma is a broad array of clinical phenotypes, it is likely that more than 100 different genes influence the onset of asthma. An incomplete list of those genes that have been most replicated and appear most central to children's asthma risk and asthma severity are highlighted in Tables 2 and 3, respectively.

One likely reason that genotype-phenotype associations are difficult to replicate is phenotypic mixing. If association studies do not enforce strict phenotypic characterization (accurate grouping by precise clinical characteristics, including atopy status, age of onset, and bronchial responsiveness) the study will suffer from a type of misclassification bias that will lead to both false discoveries and false negative errors.

A second likely reason for poor replicability is gene-phenotype effect modification by environment or epistatic genes. Important environmental modifiers for asthma can include fetal exposure to maternal smoking, and early postnatal exposure to secondhand smoke, early respiratory virus exposure, and allergens. ${ }^{4}$ One important and illustrative example is the interaction between $17 \mathrm{q} 21$ variants and early exposure to rhinovirus $^{5}$ and tobacco smoke. ${ }^{6}$ Caliskan et al who focused specifically on early onset childhood asthma, found that variants in the 17q21 genes (ORMDL3 and GSDMB) were associated with asthma only among children with previous exposure and wheezing with rhinovirus. ${ }^{5}$

Once the clinical diagnosis of asthma is made, several objective biomarkers can be called upon to supplement the child's disease, family and exposure history, and the objective clinical data including physical examination and spirometry. Each biomarker is discussed with particular emphasis on diagnostic utility and treatment management.

\section{Fractional expired nitric oxide}

The fraction of expired nitric oxide (FENO) is the most common noninvasive biomarker used for children with asthma. Nitric oxide from expired breath reacts with ozone to produce excited nitrogen dioxide and light energy which, using chemiluminescent analysis, can estimate nitric oxide 
Table 2 Genes of particular relevance to childhood asthma risk

\begin{tabular}{|c|c|c|c|c|c|}
\hline Gene & Locus & Biomarker/function & Population & Technique & Citation \\
\hline DENNDIB & Iq31.3 & $\begin{array}{l}\text { Expressed on dendritic cells, } \\
\text { interacts with TNFa }\end{array}$ & $\begin{array}{l}\text { North American Whites } \\
\text { and Blacks }\end{array}$ & GWAS & Sleiman ${ }^{1 / 3}$ \\
\hline CHI3LI & Iq32.I & $\begin{array}{l}\text { The protein, YKL- } 40 \text {, is upregulated } \\
\text { by } 15 \% \text { among asthmatics. YKL- } 40 \\
\text { is expressed by macrophages and } \\
\text { vascular SMCs and binds to chitins }\end{array}$ & $\begin{array}{l}\text { Hutterites, American } \\
\text { Whites, German, Chicago }\end{array}$ & GWAS & Ober ${ }^{1 / 4}$ \\
\hline $\begin{array}{l}\text { ILIRLI/ } \\
\text { ILI } 8 R I^{*}\end{array}$ & $2 q 11.2$ & $\begin{array}{l}\text { Encodes a protein in the Toll-like } \\
\text { receptor superfamily/encodes the } \\
\text { IL- I } 8 \text { receptor }\end{array}$ & $\begin{array}{l}\text { Icelanders, Europeans, } \\
\text { East Asians }\end{array}$ & GWAS & $\begin{array}{l}\text { Gudbjartsson }{ }^{115} \\
\text { Moffatt }^{116}\end{array}$ \\
\hline DPPIO & $2 q 14$ & IL-I gene cluster & $\begin{array}{l}\text { English and German; } \\
\text { American Blacks, } \\
\text { African Caribbean }\end{array}$ & $\begin{array}{l}\text { Linkage/positional } \\
\text { cloning; GWAS }\end{array}$ & Allen $^{117} ;$ Mathias $^{118}$ \\
\hline PDE4D & $5 q 12$ & $\begin{array}{l}\text { Phosphodiesterase } 4 D \text { is a } \\
\text { Regulator of ASM contractility }\end{array}$ & $\begin{array}{l}\text { North American } \\
\text { children (CAMP) }\end{array}$ & Association & Himes $^{119}$ \\
\hline IL4 & $5 q 31$ & Encodes IL-4 & North American Whites & Association & Basehore $^{120}$ \\
\hline PCDHI & $5 q 31-q 33$ & $\begin{array}{l}\text { Protocadherin I encodes an } \\
\text { adhesion molecule on alveolar } \\
\text { macrophages and epithelial cells }\end{array}$ & $\begin{array}{l}\text { Dutch; Netherlands, } \\
\text { UK, USA }\end{array}$ & $\begin{array}{l}\text { Linkage/positional } \\
\text { cloning }\end{array}$ & Koppelman ${ }^{121}$ \\
\hline $\begin{array}{l}\text { HLA-DR/ } \\
D Q^{*}\end{array}$ & 6p21 & MHC class II loci & American Whites & GWAS & $\mathrm{Li}^{122} ;$ Moffatt ${ }^{116}$ \\
\hline GPRA & $7 p$ & A G-protein coupled receptor & $\begin{array}{l}\text { Finnish, Canadian, } \\
\text { Australian }\end{array}$ & $\begin{array}{l}\text { Linkage/positional } \\
\text { cloning }\end{array}$ & $\begin{array}{l}\text { Daniels }{ }^{3} \text {; Laitinen }{ }^{123} \text {; } \\
\text { Leaves }^{124}\end{array}$ \\
\hline IL33* & $9 p 24$ & $\begin{array}{l}\text { Encodes IL-33, belongs to the } \\
\text { IL-I superfamily of proteins }\end{array}$ & Europeans & GWAS & Moffatt 116 \\
\hline $\begin{array}{l}\text { ORMDL3 } \\
\text { cluster* }\end{array}$ & $|7 q 2|$ & $\begin{array}{l}\text { Encodes transmembrane proteins } \\
\text { anchored in the ER, of unknown } \\
\text { function }\end{array}$ & $\begin{array}{l}\text { European, Asian, } \\
\text { Hispanics }\end{array}$ & Association, GWAS & Moffatt ${ }^{116} ;$ Caliskan ${ }^{5}$ \\
\hline ADAM33 & $20 p / 3$ & $\begin{array}{l}\text { A disintegrin and metallopeptidase } \\
\text { domain } 33 \text { membrane-bound } \\
\text { metalloprotease protein }\end{array}$ & $\begin{array}{l}\text { White sibling pairs } \\
\text { from North America } \\
\text { and UK }\end{array}$ & $\begin{array}{l}\text { Linkage/positional } \\
\text { cloning }\end{array}$ & Van Eerdewegh ${ }^{125}$ \\
\hline
\end{tabular}

Abbreviations: TNFa, tumor necrosis factor alpha; GWAS, genome-wide association study; SMC, smooth muscle cell; ASM, airway smooth muscle; CAMP, children's asthma management program; MHC, major histocompatibility complex; IL, interleukin; ER, endoplasmic reticulum.

Note: *associated with early onset asthma.

concentration. Both online and offline methods measure FENO in parts per billion. Offline measurement involves participant exhalation into an impermeable reservoir that is analyzed for nitric oxide content. Online measurement uses exhalation directly into a handheld portable device. Most children can reproducibly perform a valid 6-second maneuver required for FENO measurement, ${ }^{7,8} 64 \%$ and $93 \%$ of 6 and 8 year olds, respectively, were able to perform reproducible FENO measures. The handheld Niox Mino ${ }^{\circledR}$ (Aerocrine AB, Solna, Sweden) can be successfully used in children down to 4 years of age. ${ }^{9}$

In the pediatric age range, FENO is most closely associated with allergic and eosinophilic airway inflammation, and likely reflects the contribution of nitric oxide metabolism in airway inflammation. ${ }^{10}$ Other factors associate with FENO that are not directly related to asthma. FENO levels positively correlate with male gender, ${ }^{11}$ older age, lower body mass index, allergic sensitization, ${ }^{12}$ pollen ${ }^{13}$ or air pollution exposure, ${ }^{14}$ sputum eosinophils, ${ }^{15,16}$ persistent airway inflammation responsive to inhaled corticosteroids, ${ }^{17,18}$ Asian ethnicity ${ }^{19}$ morning time of day, ${ }^{20}$ gene polymorphisms in the nitric oxide pathway ${ }^{21}$ and acute stress. Smoking or exposure to secondhand smoke also modestly reduces FENO. ${ }^{22-24}$ Importantly, FENO does not consistently correlate with lung function ${ }^{25,26}$ or bronchial hyperreactivity. ${ }^{27}$ FENO does not closely or consistently reflect or predict asthma symptoms. ${ }^{20}$

\section{Practical uses}

FENO is one of the easiest, most feasible, and noninvasive biomarkers available, allowing point-of-care feedback in the clinical setting. In asthmatic children with elevated FENO, levels tend to drop following treatment with inhaled corticosteroids. FENO-driven monitoring and medication adjustment have been studied with the hypothesis that serial FENO measures may allow safer weaning of controller therapy and improved control. In adults, FENO-guided management has been shown to lead to modest improve- 
Table 3 Genes important to childhood asthma severity or drug response

\begin{tabular}{|c|c|c|c|c|}
\hline Gene & Locus & Protein & $\begin{array}{l}\text { Association effect (pathogenesis, } \\
\text { severity, treatment) }\end{array}$ & Citation \\
\hline SPATS2L & $2 q 33$ & $\begin{array}{l}\text { Unknown function, expressed } \\
\text { in many cell types, involved } \\
\text { in ribosomal biogenesis }\end{array}$ & $\begin{array}{l}\text { Association study, Related to bronchodilator } \\
\text { responsiveness }\end{array}$ & Himes $^{126}$ \\
\hline$A D B R 2$ & $5 q 31$ & $\begin{array}{l}\text { Beta2 adrenoreceptor; } \\
\text { Transmembrane domain receptor } \\
\text { on ASM and inflammatory cells }\end{array}$ & $\begin{array}{l}\text { Arg } 16 \text { variant is associated with improved } \\
\text { response to Beta2 agonism }\end{array}$ & $\begin{array}{l}\text { Israel }{ }^{127} ; \text { Lima }^{128} \\
\text { Martinez }^{129}\end{array}$ \\
\hline IL4 & $5 q 31$ & Encodes interleukin-4 & Associated with reduced FEVI, & Burchard ${ }^{130}$ \\
\hline$C D / 4$ & $5 q 31$ & $\begin{array}{l}\text { Encodes CDI } 4 \text { receptor } \\
\text { for lipopolysaccharide }\end{array}$ & $\begin{array}{l}\text { North American Whites } \\
\text { Associated with asthma severity with modification } \\
\text { from SHS; associated with severity; Hispanic/ } \\
\text { Latino, North American Whites, Australian }\end{array}$ & $\begin{array}{l}\text { Choudhry }{ }^{131} \\
\text { Martin }^{132}\end{array}$ \\
\hline$T$ & $6 q 27$ & $\begin{array}{l}\text { Encodes a mesodermal } \\
\text { developmental transcription factor } \\
\text { with DNA binding capability. }\end{array}$ & Association study, Response to ICS & Tantisira ${ }^{133}$ \\
\hline GLCCII & $7 p 21.3$ & Glucocorticoid inducible gene & Association study, Response to ICS & Tantisira ${ }^{109}$ \\
\hline ALOX5 & $10 q \mid 1.2$ & 5-lipoxygenase & $\begin{array}{l}\text { SpI binding motif repeat polymorphism gentoype } \\
\text { associated with improved response to ALOX5 } \\
\text { inhibitor; worse lung function and asthma control }\end{array}$ & $\begin{array}{l}\text { Drazen }{ }^{134} \\
\text { Mougey }\end{array}$ \\
\hline CRHRI & $|7 q| 2-22$ & $\begin{array}{l}\text { Intronic region of the corticotrophin } \\
\text { releasing hormone receptor I gene }\end{array}$ & Association study, Response to ICS & Tantisira ${ }^{136}$ \\
\hline $\begin{array}{l}\text { ORMDL3 } \\
\text { cluster* }\end{array}$ & $|7 q 2|$ & $\begin{array}{l}\text { Encodes transmembrane proteins } \\
\text { anchored in the ER, of unknown } \\
\text { function }\end{array}$ & $\begin{array}{l}\text { Association with exacerbations and poor } \\
\text { asthma control on controller medication, } \\
\text { Europeans }\end{array}$ & $\begin{array}{l}\text { Bisgaard }^{137} \\
\text { Tavendale }^{138}\end{array}$ \\
\hline ADAM33 & $20 p / 3$ & $\begin{array}{l}\text { A disintegrin and metallopeptidase } \\
\text { domain } 33 \text { membrane-bound }\end{array}$ & $\begin{array}{l}\text { ADAM33 increased in severe versus } \\
\text { mild asthma or no asthma, English }\end{array}$ & Foley ${ }^{139}$ \\
\hline
\end{tabular}

Abbreviations: Arg, Arginine; ASM, airway smooth muscle; ER, endoplasmic reticulum; FEVI, forced expiratory volume in I second; SHS, secondhand smoke, ICS, inhaled corticosteroids; LTM, leukotriene modifier.

ment in asthma control despite reductions in inhaled corticosteroid dose. ${ }^{28}$ The utility of FENO-driven care in children has not been robustly supported by the current data and may even lead to reduced weaning of controller steroids. ${ }^{29} \mathrm{~A}$ recent systematic review of the current evidence concluded that the routine use of FENO-based management could not be recommended. ${ }^{30}$ Despite this, FENO-guided management may be helpful in select patients. Handheld on-line FENO devices exist and have been shown to be feasible for daily home use. ${ }^{20}$ Among children with atopy and asthma, fluctuation patterns in daily FENO may predict future loss of asthma control. ${ }^{18,31}$ However, more data are needed to establish concrete practical uses of FENO in predicting poor asthma control and exacerbations. FENO may be useful in identifying patients who will respond to inhaled corticosteroids. FENO was higher 2 and 4 weeks following asthma exacerbation among patients requiring more post-exacerbation rescue treatment; and among patients not prescribed post-exacerbation inhaled corticosteroid. ${ }^{32}$ An obvious and very practical application of any biomarker in young asthmatics is the possible predictive value for later persistent wheezing. Unfortunately, FENO in toddlers with asthma symptoms added only modest improvements to the predictive abilities for later physician-diagnosed asthma during school age. ${ }^{33,34}$ A summary of practical uses for FENO is included in Table 4.

\section{Limitations}

Several important limitations exist with FENO that must be understood to maximize its practicality. Since FENO is not

Table 4 Uses of FENO in the clinic

\section{When FENO may be helpful}

I. Identifying patients who are likely to respond to inhaled corticosteroids

2. Identifying patients with allergic and eosinophilic airway inflammation

3. Establishing diagnosis of persistent asthma among patients with chronic asthma-like symptoms

4. Guiding asthma medication management in select patients with allergic/eosinophilic asthma demonstrating high pre-treatment FENO levels. FENO may help as supplemental data for determining titration of steroid dosing and adherence ${ }^{140}$

5. Adding supplemental predictive data to toddlers/young school children with asthma symptoms (will child develop persistent asthma?)

When FENO is not as helpful or should be assessed with caution

I. Determining who currently has asthma and who does not have asthma

2. Detecting poor asthma control ${ }^{140,141}$

Abbreviation: FENO, fractional exhaled nitric oxide. 
specific to asthma and may be influenced by other factors, it is not surprising that there exists considerable overlap in FENO between asthmatics and non-asthmatics. In addition, FENO is generally not a good marker of current or future asthma symptoms and is not associated with steroid-related improvements in lung function following an asthma exacerbation..$^{32}$ Optimal cutpoints to differentiate asthma and nonasthma respiratory symptoms, and controller adherence versus nonadherence, ${ }^{27}$ both remain elusive. Additionally, considerable overlap exists between asthma patients when on or off daily inhaled steroids. ${ }^{27}$ No FENO cutpoint appears to have both acceptable sensitivity and specificity. ${ }^{35}$

A recent National Institutes of Health committee on biomarkers recommended that FENO be a supplemental (rather than a core) marker for the characterization of asthma cohorts in clinical trials and observational studies. ${ }^{36}$ Areas that need further exploration include the relationships between FENO and airway remodeling, asthma control, and phenotype.

\section{Total and allergen-specific IgE}

The atopy status of a child with asthma is a very important determination for clinicians to make for both prognostication and management. Asthma with comorbid allergen sensitization typically constitutes a distinct clinical phenotype from other common pediatric phenotypes including intermittent viral-induced asthma, exercise-induced asthma, or late onset obesity-related asthma. Total serum Immunoglobulin E (IgE) generally and allergen specific IgE specifically are accepted biomarkers for atopic asthma in the clinical setting of asthma symptoms. The Phadiatop ${ }^{\mathrm{TM}}$ (Pharmacia and Upjohn, Uppsala, Sweden) multiallergen screen was recently declared a core biomarker for the description of asthma populations participating in research studies. ${ }^{36}$ It characterizes someone as atopic but does not specify which of the most common indoor and outdoor allergens are likely present. The Phadiatop assay uses the ImmunoCAP (Childhood Allergen Profile) technology with a solid-phase immunoassay for serum specific IgE. The proprietary mixture reports to include the most relevant inhalant allergens coupled with ImmunoCAP.

Total IgE has been associated with asthma ${ }^{37,38}$ and is highly age-dependent. Compared with nonatopic infants, atopic infants have an earlier rise and peak in serum IgE. Total serum IgE reaches adult levels by age 10-15 years and declines from the second decade. Still, there is considerable overlap in IgE levels between atopic and nonatopics. The presence of allergen-specific IgE in the setting of asthma and allergy symptoms defines an individual as having atopic asthma. ${ }^{39,40}$ Secondly, allergen-specific IgE can detect a likely asthma and allergy trigger that can become a focus of prevention efforts. There is a direct relationship between level of serum IgE and likelihood of wheeze and likelihood of reduced lung function. IgE serum levels to mite, cat, and dog at age 3 years are associated with an increased risk of wheeze at age 5 years, while a similar increase in wheeze was not associated with local size of skin test wheal. ${ }^{40}$

The multiallergen screen for aeroallergens (Phadiotop) plus the food allergen mix ( $\mathrm{f} \times 5)$ has generally been more effective for the characterization of asthma than measuring individual allergens. ${ }^{41,42}$ When the Phadiotop and $f \times 5$ are used in combination, they display a $97.4 \%$ positive predictive value for any suspected allergic disease, eg, asthma, allergic rhinitis, eczema, food allergy. Young children with episodic wheeze and significant elevation in the multiallergen screen are at higher risk for persistent wheeze that will continue into adolescence. These children will require close monitoring and a thoughtful asthma and allergy plan in place to reduce morbidity.

\section{Urinary leukotrienes}

Leukotrienes are formed via arachidonic acid metabolism through the 5-lipoxygenase pathway. Phospholipase $\mathrm{A}_{2}$ activates the release of arachidonic acid from inflammatory cell-membrane phospholipids which is converted to leukotriene $\mathrm{A}_{4}$ by membrane-bound 5-lipoxygenase. The latter is activated by the action of 5-lipoxygenase-activating protein. ${ }^{43}$ Leukotriene $\mathrm{A}_{4}$ hydrolase converts leukotriene $\mathrm{A}_{4}$ to leukotriene $\mathrm{B}_{4}$, or leukotriene $\mathrm{C}_{4}$ synthase conjugates leukotriene $\mathrm{A}_{4}$ with reduced glutathione to form leukotriene $\mathrm{C}_{4}{ }^{43}$ Leukotriene $\mathrm{B}_{4}$ and leukotriene $\mathrm{C}_{4}$ are transported to the extracellular space ${ }^{44,45}$ where leukotriene $\mathrm{C}_{4}$ is converted to leukotriene $\mathrm{D}_{4}$ by $\gamma$-glutamyltransferase ${ }^{46}$ Leukotriene $\mathrm{E}_{4}$ is formed from leukotriene $\mathrm{D}_{4}$ by dipeptidase. ${ }^{47}$ Biosynthesis of cysteinyl leukotrienes (leukotrienes $\mathrm{C}_{4}, \mathrm{D}_{4}$, and $\mathrm{E}_{4}$ ) occurs primarily in eosinophils, basophils, and mast cells, whereas leukotriene $\mathrm{B}_{4}$ is found largely in neutrophils, macrophages, and dendritic cells. ${ }^{43}$ The cysteinyl leukotrienes bind to and activate cys-leukotriene 1 and cys-leukotriene 2 receptors, causing bronchoconstriction, airway hyperresponsiveness and smooth muscle hypertrophy, mucus hypersecretion and mucosal edema, and influx of eosinophils into airway tissue. ${ }^{48,49}$ The most commonly used leukotriene modifier (montelukast) blocks the cys-leukotriene 1 receptor.

Formation and metabolism of cysteinyl leukotrienes occurs rapidly. Leukotriene $\mathrm{A}_{4}$ exists only as an unstable intermediate and leukotriene $\mathrm{C}_{4}$ is rapidly (in minutes) converted to leukotriene $\mathrm{D}_{4}{ }^{50}$ The latter is converted to 
leukotriene $\mathrm{E}_{4}$ over approximately 30 minutes, and within approximately 4 hours, $5 \%-16 \%$ of leukotriene $\mathrm{E}_{4}$ is excreted in the urine. ${ }^{50-52}$ As the most stable of the cysteinyl leukotrienes, urinary leukotriene $\mathrm{E}_{4}$ can provide a sensitive noninvasive measure of whole-body cysteinyl leukotriene production. ${ }^{53}$ Urinary leukotriene $\mathrm{E}_{4}$ levels (pg/mg creatinine) can be measured using an enzyme-linked immunosorbent assay commercial kit (Cayman Chemical Company, Ann Arbor, MI, USA, lower limit 25 pg/mL; Glory Science Co, Ltd, Del Rio, TX, USA, lower limit 5 pg/mL) or liquid chromatography-tandem mass spectrometry. ${ }^{54}$

\section{Urinary leukotrienes as a biomarker for disease or disease severity}

Significantly higher urinary leukotriene levels (two-fold) have been noted in patients with aspirin-sensitive asthma compared with those with aspirin-insensitive asthma or patients without asthma. ${ }^{53,55}$ Levels have not been shown to be consistently elevated in patients with stable asthma compared with controls. ${ }^{53,55}$ Aspirin-sensitive asthma with polyposis may reflect a unique phenotype associated with upregulated leukotriene biosynthesis because urinary leukotriene levels in these patients are higher than in patients with asthma and aspirin sensitivity but without polyposis. ${ }^{53}$

Children with sickle cell disease and asthma may also represent a unique disease phenotype with increased leukotriene production. Children with sickle cell disease and asthma have significantly greater urinary leukotriene levels compared with those with only asthma (151 pg/mg versus $61 \mathrm{pg} / \mathrm{mg}$ creatinine, respectively) ${ }^{56}$ although there was no difference noted in adults with sickle cell disease with and without asthma. ${ }^{57}$

Inconsistencies between disease groups may reflect the variability associated with age, because children may have higher levels than adults, or the methodology selected for detection. ${ }^{36,53}$ For this reason, intraindividual variation may be more clinically relevant than interindividual differences. In this context, patients with nocturnal asthma had urinary leukotriene levels which were higher during the 3 am to 6 am period than from $3 \mathrm{pm}$ to $6 \mathrm{pm} .{ }^{58}$ Similarly, increases in nocturnal symptoms coincided with falls in peak expiratory flow and increases in urinary leukotriene over time in young adults with asthma but only in those patients with nocturnal symptoms. ${ }^{59}$ Urinary leukotriene increases have also been associated with increased use of albuterol in children over time. ${ }^{53}$ Other studies have shown that urinary leukotriene increases during an acute asthma exacerbation and levels fall as symptoms improve. ${ }^{53}$

\section{Urinary leukotrienes as a biomarker for drug response}

In several pediatric studies of children with asthma, higher urinary leukotriene levels have predicted the clinical response to montelukast, a cys-leukotriene 1 receptor antagonist. Szefler et al found that young children (under 10 years old) with creatinine levels of $100 \mathrm{pg} / \mathrm{mg}$ or more were more likely to respond by an improvement in forced expiratory volume in one second $\left(\mathrm{FEV}_{1}\right)$ of $\geq 7.5 \% .{ }^{60}$ In another study in children, the ratio of urinary leukotrienes to exhaled nitric oxide was positively associated with response to montelukast and negatively associated with response to fluticasone propionate, an inhaled corticosteroid. ${ }^{61}$ In adolescents and adults with asthma, responders (improvements of $20 \%$ in symptom scores and albuterol use and 10\% improvement in $\mathrm{FEV}_{1}$ ) to montelukast had significantly higher urinary leukotriene levels of $225 \mathrm{pg} / \mathrm{mg}$ creatinine compared with $175 \mathrm{pg} / \mathrm{mg}$ creatinine in nonresponders. ${ }^{62}$ The National Institutes of Health committee on biomarkers strongly recommended monitoring urinary leukotriene in any study involving manipulation of the eicosanoid pathway. ${ }^{36}$ The committee recommended its use in studies that characterize asthma phenotypes, particularly aspirin-sensitive, adult-onset, and eosinophilic asthma. ${ }^{36}$

\section{Genetic variants in the leukotriene pathway and response to treatment}

Genes in the leukotriene synthesis pathway are highly polymorphic and many studies have evaluated associations between variants and response to treatment. ${ }^{63}$ The $A L O X 5$ gene located on 10q11.21 encodes ALOX5, a key enzyme in the synthesis of cysteinyl leukotrienes. ${ }^{64}$ Early studies identified addition and deletion variants (nucleotide sequences of 5'GGGCGG3' repeated in a tandem cluster where wild-type $\mathrm{n}=5$ and variant $\mathrm{n} \neq 5$ ), in the core promoter (factor $\mathrm{Sp}-1$ binding motif) of $A L O X 5$, the gene encoding 5-lipoxygenase, that were associated with diminished promoter-reporter activity in tissue culture. ${ }^{65}$ Because this is the first enzyme in the leukotriene synthesis pathway, it would be expected to exert a possibly larger influence on response than other downstream pathway genes. Indeed, early studies found that patients with asthma carrying at least one wild-type allele (five repeats) had improved outcomes after taking a 5-lipoxygenase inhibitor or montelukast compared with patients homozygous for the variant allele. ${ }^{66,67}$ Lima et al and Klotsman et al also found an association, but in these studies the carriers of the variant allele had an improved response to montelukast. ${ }^{68,69}$ A recent study examined $A L O X 5$ polymorphisms and urinary 
leukotriene concentrations and found that leukotriene levels were significantly higher in children with asthma who were homozygous for the variant allele, substantiating the work by Lima and Klotsman and suggesting that the presence of the variant allele may upregulate cysteinyl leukotriene production, leading to an enhanced response to leukotriene modifiers in those studies. ${ }^{54}$

Polymorphisms in other genes, such as CYSLTR1, LTA4H, $L T C 4 S$, and transporter genes, have also been studied for response to drug therapy, but few studies have replicated these results $^{68,70}$ (Table 5). In the largest candidate gene pharmacogenomic study, Lima et al genotyped 28 polymorphisms from ALOX5, cysLTR1, LTA4H, LTC4S, and ABCC1 (was MRP1), and associations with a beneficial response to montelukast were identified for $A B C C 1$ rs1 19774 and $A L O X 5$ rs2115819 for $\mathrm{FEV}_{1}$ response, and LTA4H rs2660845 and LTC4SA-444C (C carriers) for reduced risk of exacerbation. ${ }^{71}$ This study was repeated with zileuton and the findings for $A L O X 5$ rs 2115819 and $A B C C 1$ rs119774 were replicated. ${ }^{72}$ In another study of six pathway genes (ALOX5, LTC4S, CYSLTR1, CYSLTR2, $A L O X 5 A P, P L A 2 G 4 A$ ) with 15 polymorphisms, improvements in lung function in patients taking montelukast were observed for variants in $A L O X 5, A L O X 5$ addition/deletion, CYSLTR1, and CYSLTR2, although none replicated the findings by Lima et al. ${ }^{71}$ In the studies by Lima et al and Klotsman et al, haplotype analysis yielded additional associations with response to montelukast. ${ }^{71,73}$ In a study of zafirlukast, a cys-leukotriene-1 receptor antagonist, patients with asthma who were carriers of the $\mathrm{C}$ allele in LTC4S A-444C had greater improvements in lung function and produced more leukotriene $\mathrm{C}_{4}$ from eosinophils. ${ }^{74}$ Similarly, in a Japanese population of patients with asthma treated with pranlukast (a cys-leukotriene-1 receptor antagonist available outside the United States), carriers of the LTC4S A-444C C allele had a better lung function response compared with AA homozygotes. ${ }^{75}$ In another study of montelukast, reduction in FENO was greater (albeit not statistically significant) in carriers of the LTC4S A-444C C allele, although lack of significance may have been due to a small sample size $(n=12) .{ }^{76} \mathrm{G}$ allele carriers of the $L T A 4 H$ rs 2660845 polymorphism have also been shown to have a poorer lung function response to montelukast in Japanese patients, which supports the finding for this same polymorphism by Lima et al. ${ }^{71,77}$ Replication of findings among these studies suggests that variants in $A L O X 5$ (addition/deletion polymorphism), ALOX5 (rs2115819), ABCC1 (rs119774), LTC4S A-444C, and LTA4H (rs2660845) genes may associate with response to leukotriene modifiers.

Currently available leukotriene modifiers are administered orally, so variation in therapeutic effect may be caused by polymorphisms in genes regulating uptake and transport from the gut and metabolism in the liver. Montelukast is metabolized primarily by cytochrome P450 (CYP)2C8 in the liver $(72 \%$ of oxidative metabolism) with smaller contributions from CYP3A4 (16\%) and CYP2C9 (12\%). ${ }^{78}$ The gene encoding the hepatic CYP2C8 enzyme is highly polymorphic but no pharmacogenomic studies have been performed.

Table 5 Pharmacogenomic association studies of polymorphisms in the leukotriene pathway

\begin{tabular}{|c|c|c|c|c|}
\hline Gene & Polymorphism & Drug & Associated outcome & Reference \\
\hline ALOX5 & rs59439|48' & Montelukast & Exacerbation rate & $\operatorname{Lima}^{71}$ \\
\hline ALOX5 & rs59439|48' & 5-LO inhibitor & Lung function & Drazen $^{134}$ \\
\hline ALOX5 & rs59439|48' & Montelukast & $\begin{array}{l}\text { Lung function; exacerbation rate; } \\
\text { beta agonist use }\end{array}$ & Telleria $^{142}$ \\
\hline ALOX5 & rs21I5819 & Montelukast & Lung function & $\operatorname{Lima}^{71}$ \\
\hline ALOX5 & rs21I5819 & Zileuton & Lung function & Tantisira $^{72}$ \\
\hline ALOX5 & rs4987I05 & Montelukast & Lung function & Klotsman ${ }^{73}$ \\
\hline ALOX5 & rs4986832 & Montelukast & Lung function & Klotsman ${ }^{73}$ \\
\hline CYSLTR2 & rs91227 & Montelukast & Lung function & Klotsman ${ }^{73}$ \\
\hline CYSLTR2 & rs912278 & Montelukast & Lung function & Klotsman ${ }^{73}$ \\
\hline LTC4 & A-444C promoter & Montelukast & Lung function & Asano 75 \\
\hline LTC4 & A-444C promoter & Zafirlukast & Lung function & Sampson ${ }^{74}$ \\
\hline LTC4 & A-444C promoter & Montelukast & FENO & Whelan ${ }^{76}$ \\
\hline LTA4H & rs 2660845 & Montelukast & Lung function & Kotani ${ }^{77}$ \\
\hline LTA4H & rs2660845 & Montelukast & Exacerbation rate & $\operatorname{Lima}^{71}$ \\
\hline$A B C C I(M R P I)$ & rsII9775 & Montelukast & Lung function & $\operatorname{Lima}^{71}$ \\
\hline$A B C C I$ (MRPI) & rs II9775 & Zileuton & Lung function & Tantisira $^{72}$ \\
\hline SLCO2BI & rs 12422149 & Montelukast & $\begin{array}{l}\text { Plasma concentrations; } \\
\text { asthma control }\end{array}$ & Mougey ${ }^{79}$ \\
\hline
\end{tabular}

Note: 'rs59439/48 is an Spl tandem promoter repeat polymorphism.

Abbreviations: LO, lipoxygenase; FENO, fractional exhaled nitric oxide; SpI, serum protein I. 
An elegant study by Mougey et al confirmed that montelukast undergoes carrier-mediated uptake from the gut by OAT2B1 and OAT1A2 (encoded by SLCO2B1 and SLCO1A2, respectively). ${ }^{79} \mathrm{~A}$ variant in $S L C O 2 B 1$ (rs12422149) alters the protein coding of OAT2B1 and associates with reduced plasma concentrations of montelukast and worse asthma control. ${ }^{79}$ In summary, urinary leukotriene levels are a sensitive biomarker of changes in asthma severity and response to drug treatment, and can be collected and measured in children who are too young to provide other outcome measures in a dependable manner, such as pulmonary function, symptom scores, and albuterol use related to subjective symptom assessment. Additional research is needed to confirm findings from previous studies of the ALOX5,LTC4SA-444C, LTA4H, CYSLTR1, CYSLTR2, ABCC1, and SLCO2B1 polymorphisms before they can be reliably used to predict treatment response. In the future, ideally, leukotriene concentrations would be measured in the lung where they are biologically relevant for causing symptoms of asthma. Exhaled breath is a gaseous mixture of volatile compounds and a liquid phase collected as a condensate. The collection of exhaled breath condensate is technically simple and can be performed by children as young as 4 years and involves breathing in while holding a mouthpiece between the lips for approximately 10 minutes. Exhaled breath condensate can be quantitatively analyzed for inflammatory mediators and related constituents (8-isoprostane, nitrates, nitrites, nitrotyrosine, tumor necrosis factor-alpha) and $\mathrm{pH}$. A recent review of the exhaled breath condensate literature in pediatric asthma found that the cysteinyl leukotrienes were measurable in exhaled breath condensate, that increased levels were found in children with asthma compared with healthy controls, and higher levels were associated with increased asthma severity ${ }^{80}$ However, condenser coatings and sample handling (freeze-thaw) can significantly affect biomarker concentrations. ${ }^{81,82}$ The ECoScreen (Jaeger, Wuerzburg Germany) has been shown to measure higher levels of cysteinyl leukotrienes than the R-Tube (Respiratory Research, Inc, Charlottesville, VA, USA), possibly reflecting the impact of condenser coatings or other factors on sample stability. ${ }^{82-84}$ The R-Tube is currently widely used in large clinical trials for its lower cost and ease of sample collection compared with other devices, but at present is not suitable for measurement of cysteinyl leukotrienes.

\section{Biomarkers to assess secondhand tobacco smoke exposure}

Despite years of tobacco education, nearly $20 \%$ of US adults continue to smoke on a daily basis. ${ }^{85}$ Secondhand tobacco smoke is the primary indoor pollutant for most children, with more than 40 million US children exposed each year. ${ }^{86}$ Recent data suggest that more than half of children in the US are exposed at least intermittently to secondhand tobacco smoke. ${ }^{87}$ Secondhand tobacco smoke exposure increases the risk for reduced lung growth, sudden infant death syndrome, pneumonia, bronchitis, ear infections, and asthma. A recent large meta-analysis reported that among infants exposed to secondhand tobacco smoke, the odds of incident wheeze was increased $70 \%$ compared with those not exposed $(95 \%$ confidence interval 1.24-2.35). ${ }^{88}$ In children already with asthma, exposure to secondhand tobacco smoke can make daily asthma control very difficult to achieve and can induce severe asthma attacks. ${ }^{89,90}$ Secondhand smoke (SHS) contains over 250 toxic and carcinogenic chemicals (including arsenic, formaldehyde, and cyanide), with only small amounts needed to impose lung damage, respiratory infections, oxidant damage, airway reactivity, and asthma-like symptoms. ${ }^{91-95}$ The data linking SHS with childhood asthma are considerable. ${ }^{86,96-98}$ Asthmatic children exposed to SHS are particularly at risk for accelerated loss of lung function and worsening disease severity, ${ }^{91,93,99-102}$ and may be at increased risk for death. ${ }^{103,104}$ The mechanisms underlying passive smoking-related morbidity in children with asthma are not completely understood but may involve several mechanisms including greater acquisition of respiratory viruses which serve as asthma triggers, or upregulation of the leukotriene pathway, given that active smoking increases the production of cysteinyl leukotrienes and leukotriene B4. ${ }^{6-9}$

A reliable biomarker for the detection of recent exposure to secondhand tobacco smoke would be clinically helpful in certain scenarios. Secondhand tobacco smoke can be measured objectively from directly sampling nicotine metabolites or tobacco-specific carcinogens. Blood samples provide the most accurate assessment of exposure level occurring in the previous 72 hours. Cotinine, a primary metabolite of nicotine, can be measured in the blood, or less invasively measured in saliva, hair, and urine by reference laboratories. ${ }^{105,106}$ Cotinine has a half-life of roughly 16 hours and is completely eliminated from the body within about 3 days. ${ }^{107}$ Cotinine results are subject to short-term variations in exposure to secondhand tobacco smoke and significant within-subject variability. An alternative biomarker is 4-(methylnitrosoamino)-(3-pyridyl)1butanol (NNAL), which is a tobacco-specific carcinogen and can be measured in the urine. NNAL is usually not detectable in nonsmokers and has a considerably longer half-life (10-16 days $)^{108}$ compared with cotinine. The longer half-life of NNAL may eventually make it more useful in detecting 
Table 6 When urinary or serum cotinine may be useful*

- To assess the effectiveness of home SHS reduction measures (detection of thirdhand smoke ${ }^{143}$ )

- To assist motivated caregivers in their tobacco cessation efforts

- To determine if SHS may be present in the context of poor asthma control

- To assess if children are being exposed during visitations

$\circ$ To assess if children are being exposed in automobiles

Notes: *Detection of secondhand smoke exposure in the proper clinical context may assist the clinician and caregiver to have a better idea of how much intermittent exposure may be playing a role in poor asthma control. Knowledge gained from testing needs to be considered carefully against perceived issues of privacy.

Abbreviation: SHS, secondhand smoke.

exposure among children who have an intermittent exposure pattern. Currently, more research is needed in validating both biomarkers to improve sensitivity and specificity. Despite its infrequent use, urinary or serum cotinine measurement may be clinically helpful in select circumstances (Table 6) when a caregiver or provider is unsure of the degree of secondhand tobacco smoke to which a child is exposed.

\section{Conclusion}

How can this article help foster personalized care for asthma? Admittedly, the field of personalized medicine in the care of children with asthma is still in its infancy. Progress has been made in identifying pharmacogenetic targets for inhaled corticosteroids $^{109}$ and leukotriene modifier ${ }^{71}$ responses. We are not yet able to apply stratified asthma treatments based on genetic information, although this time may be fast approaching. The few biomarkers available to assist clinicians relate to indicators of the underlying molecular mechanisms driving asthma. FENO and serum IgE (including allergenspecific IgE), when evaluated in the context of recurrent asthma symptoms, are general predictors of allergic airway inflammation and help to guide clinicians in understanding the likely disease course and response to the most common asthma controllers. Biomarker assays for secondhand tobacco smoke exposure and cysteinyl leukotrienes are both promising areas of study that can help personalize management, not just for pharmacologic management but also education and prevention efforts.

\section{Acknowledgment}

This work was supported by grants from the James and Esther King Biomedical Research Program/Florida Department of Health (9KN0, JEL).

\section{Disclosure}

The authors report no conflicts of interest in this work.

\section{References}

1. Masoli M, Fabian D, Holt S, et al. The global burden of asthma: executive summary of the GINA Dissemination Committee report. Allergy. 2004;59:469-478.

2. Akinbami LJ, Moorman JE, Garbe PL, et al. Status of childhood asthma in the United States, 1980-2007. Pediatrics. 2009;123 Suppl 3: S131-S145.

3. Daniels SE, Bhattacharrya S, James A, et al. A genome-wide search for quantitative trait loci underlying asthma. Nature. 1996;383:247-250.

4. Vercelli D. Discovering susceptibility genes for asthma and allergy. Nat Rev Immunol. 2008;8:169-182.

5. Caliskan M, Bochkov YA, Kreiner-Moller E, et al. Rhinovirus wheezing illness and genetic risk of childhood-onset asthma. $N$ Engl J Med. 2013;368:1398-1407.

6. Bouzigon E, Corda E, Aschard H, et al. Effect of 17q21 variants and smoking exposure in early-onset asthma. $N$ Engl J Med. 2008;359: 1985-1994.

7. Jackson DJ, Sykes A, Mallia P, et al. Asthma exacerbations: origin, effect, and prevention. J Allergy Clin Immunol. 2009;128:1165-1174.

8. Ito Y, Adachi Y, Itazawa T, et al. Comparison of exhalation time methods ( $6 \mathrm{sec}$ vs $10 \mathrm{sec}$ ) of a hand-held exhaled nitric oxide analyzer. Pediatr Pulmonol. 2010;45:1005-1008.

9. Kalliola S, Malmberg P, Rito T, et al. Can we use portable nitric oxide analyzer in young children? Pediatr Pulmonol. 2011;46:627-631.

10. Riccioni G, Bucciarelli V, Verini M, et al. ADMA, SDMA, L-Arginine and nitric oxide in allergic pediatric bronchial asthma. J Biol Regul Homeost Agents. 2012;26:561-566.

11. Ishizuka T, Matsuzaki S, Aoki H, et al. Prevalence of asthma symptoms based on the European Community Respiratory Health Survey questionnaire and FENO in university students: gender differences in symptoms and FENO. Allergy Asthma Clin Immunol. 2011; $7: 15$.

12. Silvestri M, Pistorio A, Battistini E, et al. IgE in childhood asthma: relevance of demographic characteristics and polysensitisation. Arch Dis Child. 2010;95:979-984.

13. Vahlkvist S, Sinding M, Skamstrup K, et al. Daily home measurements of exhaled nitric oxide in asthmatic children during natural birch pollen exposure. J Allergy Clin Immunol. 2006;117:1272-1276.

14. Delfino RJ, Staimer N, Gillen D, et al. Personal and ambient air pollution is associated with increased exhaled nitric oxide in children with asthma. Environ Health Perspect. 2006;114:1736-1743.

15. Oguzulgen IK, Turktas H, Erbas D. Airway inflammation in premenstrual asthma. J Asthma. 2002;39:517-522.

16. Schleich FN, Seidel L, Sele J, et al. Exhaled nitric oxide thresholds associated with a sputum eosinophil count $>/=3 \%$ in a cohort of unselected patients with asthma. Thorax. 2010;65:1039-1044.

17. Mahut B, Peyrard S, Delclaux C. Exhaled nitric oxide and clinical phenotypes of childhood asthma. Respir Res. 2011;12:65.

18. van der Valk RJ, Caudri D, Savenije O, et al. Childhood wheezing phenotypes and FeNO in atopic children at age 8. Clin Exp Allergy. 2012;42:1329-1336.

19. Linn WS, Rappaport EB, Berhane KT, et al. Exhaled nitric oxide in a population-based study of southern California schoolchildren. Respir Res. 2009;10:28.

20. Pijnenburg MW, Floor SE, Hop WC, et al. Daily ambulatory exhaled nitric oxide measurements in asthma. Pediatr Allergy Immunol. 2006;17:189-193.

21. Salam MT, Byun HM, Lurmann F, et al. Genetic and epigenetic variations in inducible nitric oxide synthase promoter, particulate pollution, and exhaled nitric oxide levels in children. J Allergy Clin Immunol. 2011;129:232-239 e231-e237.

22. Bessa V, Tseliou E, Bakakos P, et al. Noninvasive evaluation of airway inflammation in asthmatic patients who smoke: implications for application in clinical practice. Ann Allergy Asthma Immunol. 2008;101:226-232; quiz 232-224, 278.

23. Perzanowski MS, Divjan A, Mellins RB, et al. Exhaled NO among inner-city children in New York City. J Asthma. 2010;47:1015-1021. 
24. de la Riva-Velasco E, Krishnan S, Dozor AJ. Relationship between exhaled nitric oxide and exposure to low-level environmental tobacco smoke in children with asthma on inhaled corticosteroids. J Asthma. 49:673-678.

25. Turktas H, Oguzulgen K, Kokturk N, et al. Correlation of exhaled nitric oxide levels and airway inflammation markers in stable asthmatic patients. J Asthma. 2003;40:425-430.

26. Jackson DJ, Virnig CM, Gangnon RE, et al. Fractional exhaled nitric oxide measurements are most closely associated with allergic sensitization in school-age children. J Allergy Clin Immunol. 2009;124: 949-953.

27. Buchvald F, Eiberg H, Bisgaard H. Heterogeneity of FeNO response to inhaled steroid in asthmatic children. Clin Exp Allergy. 2003;33: 1735-1740

28. Hewitt RS, Modrich CM, Cowan JO, et al. Outcomes using exhaled nitric oxide measurements as an adjunct to primary care asthma management. Prim Care Respir J. 2009;18:320-327.

29. Jartti T, Wendelin-Saarenhovi M, Heinonen I, et al. Childhood asthma management guided by repeated FeNO measurements: a meta-analysis. Paediatr Respir Rev. 2012;13:178-183.

30. Petsky HL, Cates CJ, Lasserson TJ, et al. A systematic review and metaanalysis: tailoring asthma treatment on eosinophilic markers (exhaled nitric oxide or sputum eosinophils). Thorax. 2012;67:199-208.

31. Stern G, de Jongste J, van der Valk R, et al. Fluctuation phenotyping based on daily fraction of exhaled nitric oxide values in asthmatic children. J Allergy Clin Immunol. 2011;128:293-300.

32. Debley JS, Cochrane ES, Redding GJ, et al. Lung function and biomarkers of airway inflammation during and after hospitalization for acute exacerbations of childhood asthma associated with viral respiratory symptoms. Ann Allergy Asthma Immunol. 2012;109:114-120.

33. Singer F, Luchsinger I, Inci D, et al. Exhaled nitric oxide in symptomatic children at preschool age predicts later asthma. Allergy. 2013;68: 531-538.

34. Klaassen EM, van de Kant KD, Jobsis Q, et al. Symptoms, but not a biomarker response to inhaled corticosteroids, predict asthma in preschool children with recurrent wheeze. Mediators Inflamm. 2012;2012: 162571.

35. Arora R, Thornblade CE, Dauby PA, et al. Exhaled nitric oxide levels in military recruits with new onset asthma. Allergy Asthma Proc. 2006;27:493-498.

36. Szefler SJ, Wenzel S, Brown R, et al. Asthma outcomes: biomarkers. J Allergy Clin Immunol. 2012;129:S9-S23.

37. Burrows B, Martinez FD, Cline MG, et al. The relationship between parental and children's serum IgE and asthma. Am J Respir Crit Care Med. 1995;152:1497-1500.

38. Sherrill DL, Lebowitz MD, Halonen M, et al. Longitudinal evaluation of the association between pulmonary function and total serum IgE. Am J Respir Crit Care Med. 1995;152:98-102.

39. Sly PD, Boner AL, Bjorksten B, et al. Early identification of atopy in the prediction of persistent asthma in children. Lancet. 2008;372: 1100-1106.

40. Simpson A, Soderstrom L, Ahlstedt S, et al. IgE antibody quantification and the probability of wheeze in preschool children. JAllergy Clin Immunol. 2005;116:744-749.

41. Wickman M, Ahlstedt S, Lilja G, et al. Quantification of IgE antibodies simplifies the classification of allergic diseases in 4-year-old children. A report from the prospective birth cohort study - BAMSE. Pediatr Allergy Immunol. 2003;14:441-447.

42. Wickman M, Lilja G, Soderstrom L, et al. Quantitative analysis of IgE antibodies to food and inhalant allergens in 4-year-old children reflects their likelihood of allergic disease. Allergy. 2005;60:650-657.

43. Peters-Golden M, Henderson WR Jr. Leukotrienes. $N$ Engl J Med. 2007;357:1841-1854

44. Lam BK, Owen WF Jr, Austen KF, et al. The identification of a distinct export step following the biosynthesis of leukotriene C4 by human eosinophils. J Biol Chem. 1989;264:12885-12889.
45. Kawabe T, Chen ZS, Wada M, et al. Enhanced transport of anticancer agents and leukotriene $\mathrm{C} 4$ by the human canalicular multispecific organic anion transporter (cMOAT/MRP2). FEBS Lett. 1999;456:327-331.

46. Anderson ME, Allison RD, Meister A. Interconversion of leukotrienes catalyzed by purified gamma-glutamyl transpeptidase: concomitant formation of leukotriene D4 and gamma-glutamyl amino acids. Proc Natl Acad Sci U S A. 1982;79:1088-1091.

47. Lee CW, Lewis RA, Corey EJ, et al. Conversion of leukotriene D4 to leukotriene E4 by a dipeptidase released from the specific granule of human polymorphonuclear leucocytes. Immunology. 1983;48:27-35.

48. Drazen JM, Austen KF. Leukotrienes and airway responses. Am Rev Respir Dis. 1987;136:985-998.

49. Salvi SS, Krishna MT, Sampson AP, et al. The anti-inflammatory effects of leukotriene-modifying drugs and their use in asthma. Chest. 2001;119:1533-1546.

50. Dahlen SE, Kumlin M, Bjorck T, et al. Airway smooth muscle and disease workshop: leukotrienes and related eicosanoids. Am Rev Respir Dis. 1987;136:S24-S28.

51. Sala A, Voelkel N, Maclouf J, et al. Leukotriene E4 elimination and metabolism in normal human subjects. J Biol Chem. 1990;265:21771-21778.

52. Maltby NH, Taylor GW, Ritter JM, et al. Leukotriene C4 elimination and metabolism in man. J Allergy Clin Immunol. 1990;85:3-9.

53. Rabinovitch N. Urinary leukotriene E4. Immunol Allergy Clin North Am. 2007;27:651-664.

54. Mougey E, Lang J, Allayee H, et al. ALOX5 Polymorphism Associates with Increased Leukotriene Production and Reduced Lung Function and Asthma Control in Children with Poorly Controlled Asthma. Clin Exp Allergy. 2013. Accepted manuscript online: December 22, 2012.

55. Smith CM, Hawksworth RJ, Thien FC, et al. Urinary leukotriene E4 in bronchial asthma. Eur Respir J. 1992;5:693-699.

56. Jennings JE, Ramkumar T, Mao J, et al. Elevated urinary leukotriene E4 levels are associated with hospitalization for pain in children with sickle cell disease. Am J Hematol. 2008;83:640-643.

57. Field JJ, Krings J, White NL, et al. Urinary cysteinyl leukotriene E(4) is associated with increased risk for pain and acute chest syndrome in adults with sickle cell disease. Am J Hematol. 2009;84:158-160.

58. Kurokawa K, Tanaka H, Tanaka S, et al. Circadian characteristics of urinary leukotriene $\mathrm{E}(4)$ in healthy subjects and nocturnal asthmatic patients. Chest. 2001;120:1822-1828.

59. Bellia V, Bonanno A, Cibella F, et al. Urinary leukotriene E4 in the assessment of nocturnal asthma. J Allergy Clin Immunol. 1996; 97:735-741

60. Szefler SJ, Phillips BR, Martinez FD, et al. Characterization of withinsubject responses to fluticasone and montelukast in childhood asthma. J Allergy Clin Immunol. 2005;115:233-242.

61. Rabinovitch N, Graber NJ, Chinchilli VM, et al. Urinary leukotriene E4/exhaled nitric oxide ratio and montelukast response in childhood asthma. J Allergy Clin Immunol. 2010;126:545-551 e541-e544.

62. Cai C, Yang J, Hu S, et al. Relationship between urinary cysteinyl leukotriene E4 levels and clinical response to antileukotriene treatment in patients with asthma. Lung. 2007;185:105-112.

63. Tse SM, Tantisira K, Weiss ST. The pharmacogenetics and pharmacogenomics of asthma therapy. Pharmacogenomics J. 2011;11:383-392.

64. Kanaoka Y, Boyce JA. Cysteinyl leukotrienes and their receptors: cellular distribution and function in immune and inflammatory responses. J Immunol. 2004;173:1503-1510.

65. In KH, Asano K, Beier D, et al. Naturally occurring mutations in the human 5-lipoxygenase gene promoter that modify transcription factor binding and reporter gene transcription. J Clin Invest. 1997;99:1130-1137.

66. Drazen JM, Israel E, O’Byrne PM. Treatment of asthma with drugs modifying the leukotriene pathway. N Engl J Med. 1999;340:197-206.

67. Telleria JJ, Blanco-Quiros A, Varillas D, et al. ALOX5 promoter genotype and response to montelukast in moderate persistent asthma. Respir Med. 2008;102:857-861. 
68. Lima JJ, Zhang S, Grant A, et al. Influence of leukotriene pathway polymorphisms on response to montelukast in asthma. Am J Respir Crit Care Med. 2006;173:379-385.

69. Klotsman M, York TP, Pillai SG, et al. Pharmacogenetics of the 5-lipoxygenase biosynthetic pathway and variable clinical response to montelukast. Pharmacogenet Genomics. 2007;17:189-196.

70. Mougey EB, Feng H, Castro M, et al. Absorption of montelukast is transporter mediated: a common variant of OATP2B1 is associated with reduced plasma concentrations and poor response. Pharmacogenet Genomics. 2009; 19:129-138.

71. Lima JJ, Zhang S, Grant A, et al. Influence of leukotriene pathway polymorphisms on response to montelukast in asthma. Am J Respir Crit Care Med. 2006;173:379-385.

72. Tantisira KG, Lima J, Sylvia J, et al. 5-lipoxygenase pharmacogenetics in asthma: overlap with Cys-leukotriene receptor antagonist loci. Pharmacogenet Genomics. 2009;19:244-247.

73. Klotsman M, York TP, Pillai SG, et al. Pharmacogenetics of the 5-lipoxygenase biosynthetic pathway and variable clinical response to montelukast. Pharmacogenet Genomics. 2007;17:189-196.

74. Sampson AP, Siddiqui S, Buchanan D, et al. Variant LTC(4) synthase allele modifies cysteinyl leukotriene synthesis in eosinophils and predicts clinical response to zafirlukast. Thorax. 2000;55 Suppl 2: S28-S31.

75. Asano K, Shiomi T, Hasegawa N, et al. Leukotriene C4 synthase gene $\mathrm{A}(-444) \mathrm{C}$ polymorphism and clinical response to a CYS-LT(1) antagonist, pranlukast, in Japanese patients with moderate asthma. Pharmacogenetics. 2002;12:565-570.

76. Whelan GJ, Blake K, Kissoon N, et al. Effect of montelukast on timecourse of exhaled nitric oxide in asthma: influence of LTC4 synthase A(-444)C polymorphism. Pediatr Pulmonol. 2003;36:413-420.

77. Kotani H, Kishi R, Mouri A, et al. Influence of leukotriene pathway polymorphisms on clinical responses to montelukast in Japanese patients with asthma. J Clin Pharm Ther. 2012;37:112-116.

78. Filppula AM, Laitila J, Neuvonen PJ, et al. Reevaluation of the microsomal metabolism of montelukast: major contribution by CYP2C8 at clinically relevant concentrations. Drug Metab Dispos. 2011;39:904-911.

79. Mougey EB, Feng H, Castro M, et al. Absorption of montelukast is transporter mediated: a common variant of OATP2B1 is associated with reduced plasma concentrations and poor response. Pharmacogenet Genomics. 2009;19:129-138.

80. Ahmadzai H, Huang S, Hettiarachchi R, et al. Exhaled breath condensate: a comprehensive update. Clin Chem Lab Med. 2013:1-19.

81. Rosias PP, Robroeks CM, Niemarkt HJ, et al. Breath condenser coatings affect measurement of biomarkers in exhaled breath condensate. Eur Respir J. 2006;28:1036-1041.

82. Montuschi P. Analysis of exhaled breath condensate in respiratory medicine: methodological aspects and potential clinical applications. Ther Adv Respir Dis. 2007;1:5-23.

83. Soyer OU, Dizdar EA, Keskin O, et al. Comparison of two methods for exhaled breath condensate collection. Allergy. 2006;61:1016-1018.

84. Czebe K, Barta I, Antus B, et al. Influence of condensing equipment and temperature on exhaled breath condensate $\mathrm{pH}$, total protein and leukotriene concentrations. Respir Med. 2008;102:720-725.

85. CDC. Vital signs: current cigarette smoking among adults aged $>/=18$ years - United States, 2005-2010. MMWR Morb Mortal Wkly Rep. 2011;60:1207-1212.

86. Moritsugu KP. The 2006 Report of the Surgeon General: the health consequences of involuntary exposure to tobacco smoke. Am J Prev Med. 2007;32:542-543.

87. CDC. Vital Signs: nonsmokers' exposure to secondhand smoke United States, 1999-2008. MMWR Morb Mortal Wkly Rep. 2010;59: 1141-1146.

88. Burke H, Leonardi-Bee J, Hashim A, et al. Prenatal and passive smoke exposure and incidence of asthma and wheeze: systematic review and meta-analysis. Pediatrics. 2012;129:735-744.
89. United States. Public Health Service. Office of the Surgeon General. The health consequences of involuntary exposure to tobacco smoke: a report of the Surgeon General. Rockville, MD: US Dept of Health and Human Services, Public Health Service, Office of the Surgeon General, 2006.

90. DiFranza JR, Aligne CA, Weitzman M. Prenatal and postnatal environmental tobacco smoke exposure and children's health. Pediatrics. 2004;113:1007-1015.

91. Evans D, Levison MJ, Feldman $\mathrm{CH}$, et al. The impact of passive smoking on emergency room visits of urban children with asthma. Am Rev Respir Dis. 1987;135:567-572.

92. Murray AB, Morrison BJ. Passive smoking and the seasonal difference of severity of asthma in children. Chest. 1988;94:701-708.

93. Weitzman M, Gortmaker S, Walker DK, et al. Maternal smoking and childhood asthma. Pediatrics. 1990;85:505-511.

94. Chilmonczyk BA, Salmun LM, Megathlin KN, et al. Association between exposure to environmental tobacco smoke and exacerbations of asthma in children. $N$ Engl J Med. 1993;328:1665-1669.

95. Lodrup Carlsen KC, Carlsen KH. Effects of maternal and early tobacco exposure on the development of asthma and airway hyperreactivity. Curr Opin Allergy Clin Immunol. 2001;1:139-143.

96. Goksor E, Amark M, Alm B, et al. The impact of pre- and post-natal smoke exposure on future asthma and bronchial hyper-responsiveness. Acta Paediatr. 2007;96:1030-1035.

97. Cook DG, Strachan DP. Health effects of passive smoking. 3. Parental smoking and prevalence of respiratory symptoms and asthma in school age children. Thorax. 1997;52:1081-1094.

98. Mannino DM, Moorman JE, Kingsley B, et al. Health effects related to environmental tobacco smoke exposure in children in the United States: data from the Third National Health and Nutrition Examination Survey. Arch Pediatr Adolesc Med. 2001;155:36-41.

99. Murray AB, Morrison BJ. The effect of cigarette smoke from the mother on bronchial responsiveness and severity of symptoms in children with asthma. J Allergy Clin Immunol. 1986;77:575-581.

100. Murray AB, Morrison BJ. Passive smoking by asthmatics: its greater effect on boys than on girls and on older than on younger children. Pediatrics. 1989;84:451-459.

101. O'Connor GT, Weiss ST, Tager IB, et al. The effect of passive smoking on pulmonary function and nonspecific bronchial responsiveness in a population-based sample of children and young adults. Am Rev Respir Dis. 1987;135:800-804.

102. Martinez FD, Antognoni G, Macri F, et al. Parental smoking enhances bronchial responsiveness in nine-year-old children. Am Rev Respir Dis. 1988;138:518-523.

103. Marquette CH, Saulnier F, Leroy O, et al. Long-term prognosis of nearfatal asthma. A 6-year follow-up study of 145 asthmatic patients who underwent mechanical ventilation for a near-fatal attack of asthma. Am Rev Respir Dis. 1992;146:76-81.

104. Osborne ML, Pedula KL, O’Hollaren M, et al. Assessing future need for acute care in adult asthmatics: the Profile of Asthma Risk Study: a prospective health maintenance organization-based study. Chest. 2007; 132:1151-1161.

105. Quest. Cotinine, Urine, 2013.

106. Mayo Clinic ML. Nicotine and Metabolites, Urine, 2013.

107. Benowitz NL. Cotinine as a biomarker of environmental tobacco smoke exposure. Epidemiol Rev. 1996;18:188-204.

108. Goniewicz ML, Havel CM, Peng MW, et al. Elimination kinetics of the tobacco-specific biomarker and lung carcinogen 4-(methylnitrosamino)-1-(3-pyridyl)-1-butanol. Cancer Epidemiol Biomarkers Prev. 2009;18:3421-3425.

109. Tantisira KG, Lasky-Su J, Harada M, et al. Genomewide association between GLCCI1 and response to glucocorticoid therapy in asthma. N Engl J Med. 2011;365:1173-1183.

110. Yoshikawa T, Shoji S, Fujii T, et al. Severity of exercise-induced bronchoconstriction is related to airway eosinophilic inflammation in patients with asthma. Eur Respir J. 1998;12:879-884. 
111. Reiss TF, Hill JB, Harman E, et al. Increased urinary excretion of LTE4 after exercise and attenuation of exercise-induced bronchospasm by montelukast, a cysteinyl leukotriene receptor antagonist. Thorax. 1997;52:1030-1035.

112. De Gouw HW, Marshall-Partridge SJ, Van Der Veen H, et al. Role of nitric oxide in the airway response to exercise in healthy and asthmatic subjects. J Appl Physiol. 2001;90:586-592.

113. Sleiman PM, Flory J, Imielinski M, et al. Variants of DENND1B associated with asthma in children. $N$ Engl J Med. 2010;362:36-44.

114. Ober C, Tan Z, Sun Y, et al. Effect of variation in CHI3L1 on serum YKL-40 level, risk of asthma, and lung function. $N$ Engl J Med. 2008;358:1682-1691.

115. Gudbjartsson DF, Bjornsdottir US, Halapi E, et al. Sequence variants affecting eosinophil numbers associate with asthma and myocardial infarction. Nat Genet. 2009;41:342-347.

116. Moffatt MF, Gut IG, Demenais F, et al. A large-scale, consortiumbased genomewide association study of asthma. $N$ Engl J Med. 2010;363:1211-1221.

117. Allen M, Heinzmann A, Noguchi E, et al. Positional cloning of a novel gene influencing asthma from chromosome 2q14. Nat Genet. 2003;35:258-263.

118. Mathias RA, Grant AV, Rafaels N, et al. A genome-wide association study on African-ancestry populations for asthma. J Allergy Clin Immunol. 2010;125:336-346 e334.

119. Himes BE, Hunninghake GM, Baurley JW, et al. Genome-wide association analysis identifies PDE4D as an asthma-susceptibility gene. Am J Hum Genet. 2009;84:581-593.

120. Basehore MJ, Howard TD, Lange LA, et al. A comprehensive evaluation of IL4 variants in ethnically diverse populations: association of total serum IgE levels and asthma in white subjects. J Allergy Clin Immunol. 2004;114:80-87.

121. Koppelman GH, Meyers DA, Howard TD, et al. Identification of PCDH1 as a novel susceptibility gene for bronchial hyperresponsiveness. Am J Respir Crit Care Med. 2009;180:929-935.

122. Li X, Howard TD, Zheng SL, et al. Genome-wide association study of asthma identifies RAD50-IL13 and HLA-DR/DQ regions. J Allergy Clin Immunol. 2010;125:328-335 e311.

123. Laitinen T, Daly MJ, Rioux JD, et al. A susceptibility locus for asthmarelated traits on chromosome 7 revealed by genome-wide scan in a founder population. Nat Genet. 2001;28:87-91.

124. Leaves NI, Bhattacharyya S, Wiltshire S, et al. A detailed genetic map of the chromosome 7 bronchial hyper-responsiveness locus. Eur J Hum Genet. 2002;10:177-182.

125. Van Eerdewegh P, Little RD, Dupuis J, et al. Association of the ADAM33 gene with asthma and bronchial hyperresponsiveness. Nature. 2002;418:426-430.

126. Himes BE, Jiang X, Hu R, et al. Genome-wide association analysis in asthma subjects identifies SPATS2L as a novel bronchodilator response gene. PLoS Genet. 2012;8:e1002824.

127. Israel E, Drazen JM, Liggett SB, et al. The effect of polymorphisms of the beta(2)-adrenergic receptor on the response to regular use of albuterol in asthma. Am J Respir Crit Care Med. 2000;162:75-80.

128. Lima JJ, Thomason DB, Mohamed MH, et al. Impact of genetic polymorphisms of the beta2-adrenergic receptor on albuterol bronchodilator pharmacodynamics. Clin Pharmacol Ther. 1999;65:519-525.
129. Martinez FD, Graves PE, Baldini M, et al. Association between genetic polymorphisms of the beta2-adrenoceptor and response to albuterol in children with and without a history of wheezing. $J$ Clin Invest. 1997;100:3184-3188.

130. Burchard EG, Silverman EK, Rosenwasser LJ, et al. Association between a sequence variant in the IL-4 gene promoter and FEV(1) in asthma. Am J Respir Crit Care Med. 1999;160:919-922.

131. Choudhry S, Avila PC, Nazario S, et al. CD14 tobacco geneenvironment interaction modifies asthma severity and immunoglobulin E levels in Latinos with asthma. Am J Respir Crit Care Med. 2005;172: 173-182.

132. Martin AC, Laing IA, Khoo SK, et al. Acute asthma in children: Relationships among CD14 and CC16 genotypes, plasma levels, and severity. Am J Respir Crit Care Med. 2006;173:617-622.

133. Tantisira KG, Damask A, Szefler SJ, et al. Genome-wide association identifies the T gene as a novel asthma pharmacogenetic locus. Am J Respir Crit Care Med. 2012;185:1286-1291.

134. Drazen JM, Yandava CN, Dube L, et al. Pharmacogenetic association between ALOX5 promoter genotype and the response to anti-asthma treatment. Nat Genet. 1999;22:168-170.

135. Mougey E, Lang JE, Allayee H, et al. ALOX5 Polymorphism associates with increased leukotriene production and reduced lung function and asthma control in children with poorly controlled asthma. Clin Exp Allergy. 2012;43:512-520.

136. Tantisira KG, Lake S, Silverman ES, et al. Corticosteroid pharmacogenetics: association of sequence variants in CRHR1 with improved lung function in asthmatics treated with inhaled corticosteroids. Hum Mol Genet. 2004;13:1353-1359.

137. Bisgaard H, Bonnelykke K, Sleiman PM, et al. Chromosome 17q21 gene variants are associated with asthma and exacerbations but not atopy in early childhood. Am J Respir Crit Care Med. 2009;179: 179-185.

138. Tavendale R, Macgregor DF, Mukhopadhyay S, et al. A polymorphism controlling ORMDL3 expression is associated with asthma that is poorly controlled by current medications. J Allergy Clin Immunol. 2008;121:860-863.

139. Foley SC, Mogas AK, Olivenstein R, et al. Increased expression of ADAM33 and ADAM8 with disease progression in asthma. J Allergy Clin Immunol. 2007;119:863-871.

140. Vijverberg SJ, Koster ES, Koenderman L, et al. Exhaled NO is a poor marker of asthma control in children with a reported use of asthma medication: a pharmacy-based study. Pediatr Allergy Immunol. 2012;23:529-536.

141. Yavuz ST, Civelek E, Sahiner UM, et al. Identifying uncontrolled asthma in children with the childhood asthma control test or exhaled nitric oxide measurement. Ann Allergy Asthma Immunol. 2012;109: 36- 40 .

142. Telleria JJ, Blanco-Quiros A, Varillas D, et al. ALOX5 promoter genotype and response to montelukast in moderate persistent asthma. Respir Med. 2008;102:857-861.

143. Jones IA, St Helen G, Meyers MJ, et al. Biomarkers of secondhand smoke exposure in automobiles. Tob Control. 2013. [Epub ahead of print].
Pharmacogenomics and Personalized Medicine

\section{Publish your work in this journal}

Pharmacogenomics and Personalized Medicine is an international, peerreviewed, open access journal characterizing the influence of genotype on pharmacology leading to the development of personalized treatment programs and individualized drug selection for improved safety, efficacy and sustainability. This journal is indexed on the American Chemical
Dovepress

Society's Chemical Abstracts Service (CAS). The manuscript management system is completely online and includes a very quick and fair peer-review system, which is all easy to use. Visit http://www.dovepress. $\mathrm{com} /$ testimonials.php to read real quotes from published authors. 